\title{
歯車の歯みぞのふれ測定についで
}

\author{
内 山 弘**
}

On the Measurement of Runout of Gear Teeth

\section{Hiroshi UchiYama}

Runout measurements are widely used because their results can be easily obtained. However, the meaning of information obtained from data of runout measurement is not always clear.

Purpose of the present paper is to make clear the meaning of runout. From analytical and experimental results, the following conclusions are derived.

(1) Runout is calculated using accumulated pitch errors on a right and the adjacent left tooth flank in a gear, namely from

$$
f_{r n}=\left(F_{L n}-F_{R n}\right) / \tan \phi, \phi=\pi / 2 Z-\operatorname{inv} \alpha_{0}+\tan \alpha-2 x \tan \alpha_{0} / Z
$$

where $F_{L n}$ and $F_{R n}$ are accumulated pitch errors on both flanks, $Z$ is the number of teeth, $\alpha_{0}$ is standard pressure angle, $\alpha$ is pressure angle at the measuring point and $x$ is coefficient of profile shift.

(2) Runout measurement is effective for determining the eccentricity and the errors resulting from the worm cyclic error in the gear generating machine.

(3) To obtain the worm cyclic error with high magnification, it is desirable to use a feeler diameter $\left(d_{B}\right)$ estimated from the following equation,

$$
d_{B}=d_{g} \cdot\left\{\tan \left(\pi / 2 J+\alpha_{0}\right)-\left(\pi / 2 J-\pi / 2 Z+\tan \alpha_{0}+2 x \tan \alpha_{0} / Z\right)\right\}
$$

where $d_{g}$ is base circle diameter and $J$ is number of waves in worm cyclic error.

\section{1. まえがき}

歯みぞのふれは測定がきわめて容易であり，特別の測 定器を用意しなくても測定が行なえるために広く普及し ている.特にピッチ誤差や歯形誤差の測定が困難な小形 歯車には両歯面か久あい試験とともに広く使用されてい る。しかしながら，これまでは歯みぞのふれの意味が必 ずしも明確ではなかったように思われる。ここで法その 意味を明らかにし，歯みぞのふれ測定に際して注意すべ きことがらを指摘し，さらに類似の測定法である両歯面 かみあい試験やオーバピン法との関連について検討す ל.

\section{2. 歯みぞのふれの表わすもの}

歯みごのふれ注またなピンなどの測 定子を歯みぞの両側歯面に接触させて歯 みぞの幅の不同を測定子の歯車半径方向 に対する变位として測定するものである から, 測定子が歯車の半径 $r$ 点で歯面

*原稿受付 昭和44年12月19日. 昭和44年 度精機学会秋季大会学術講演会 (昭和 44 年10月11日）にて発表.

**正会員 東京工業大学精密工学研究所 （東京都目黑区大岡山 2-12-1)
に接するものとすると, 図 1 で歯 $(Z)-(1)$ 間の弧の長さ を $l_{0}$ と新けば，歯(1)-(2) 間の長さは

$$
\Delta l_{1}=l_{0}+l_{R 1}-l_{L 1}=l_{0}+\left(t+F_{R 1}\right)-\left(t+F_{L 1}\right)=l_{0}+F_{R 1}
$$

$-F_{L 1}$ ここで $t=2 \pi r / Z$. 他の歯間についても同様で

$$
\begin{aligned}
& \Delta l_{2}=l_{0}+F_{R 2}-F_{L 1} \\
& \vdots \\
& \Delta l_{n}=l_{0}+F_{R n}-F_{L n} \\
& \vdots \\
& \Delta l_{z}=l_{0}
\end{aligned}
$$

歯 $(Z)$-(1) 間の長さ，すなわち $l_{0}=\Delta l_{Z}$ を基準にずると 他の歯間の長さは

$$
\begin{gathered}
\Delta l_{1}{ }^{\prime}=F_{R 1}-F_{L 1} \\
\vdots \\
\Delta l^{\prime}{ }_{n}=F_{R n}-F_{L n}
\end{gathered}
$$
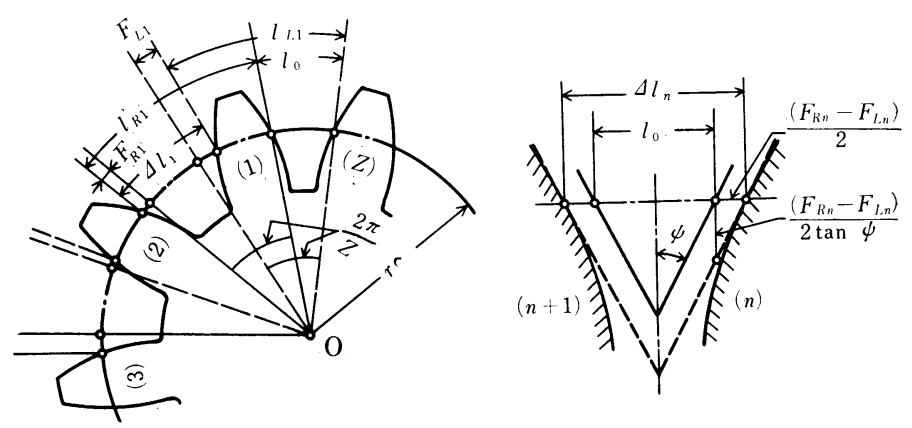

図 1 歯みぞのふれ説明 


$$
\vdots l_{Z}=0
$$

ここで $F_{L n}, F_{R n}$ 注図 1 の左図から明らかのように左右 菌面の歯 $(Z),(1)$ からの累積ピッチ誤差である. 歯みぞ のふれは歯みぞの幅が基準より大きいときに負と表示す るので図の右図を参照して,$n$ 番目の歯みぞのふれは

$$
\begin{aligned}
& f_{r n}=-\left(F_{R n}-F_{L n}\right) / 2 \tan \psi \\
& \quad\left(\phi=\pi / 2 Z-\operatorname{inv} \alpha_{0}+\tan \alpha-2 x \tan \alpha_{0} / Z\right)(1)^{1)}
\end{aligned}
$$

ここで $Z$ 注歯数， $\alpha_{0}$ 法基準圧力角， $\alpha$ 注測定子接触点の 圧力角, $x$ 注転位係数である. 式(1)に示されるように歯 タぞのふれは左右歯面の累積ピッチ誤差の差を歯車の半 径方向に換算したものであり，したがって従来歯みぞの ふれの测定はもっぱら偏心の測定と定義されていたけれ ども，むしろ累積ピッチ誤差の簡易測定法とみなすのが 妥当と思われる。なお(1)式から歯みぞのふれの大きさは 一般には $\phi$ の值により変化するので, 測定值には必ず使 用測定子径あるいは測定子接触点の半径等を併記しなけ ればならない2 ${ }^{2)}$. 測定子径 $\left(d_{B}=2 r_{B}\right)$ と歯面上の測定 子接触点の半径 $(r)$ あるい㢺触点の圧力角 $(\alpha)$ との間 の関係注 2 からつぎのように求まる。

$$
\begin{aligned}
& r=r_{g} / \cos \alpha \\
& r_{B} / r_{g}=d_{B} / d_{g}=\tan \left\{\pi / 2 Z-\operatorname{inv} \alpha_{0}\right. \\
& \left.\quad+\tan \alpha-2 x \tan \alpha_{0} / Z\right\}-\tan \alpha
\end{aligned}
$$

\section{3. 各種累積ピッチ誤差と歯みぞのふれ}

歯車加工法の種類や工作物の取付け誤差などにより歯 車には種々の形状の累積ピッチ誤差が生じる. 以下各種 累積ピッチ誤差と歯夕ぞのふれの関係について検討す る.

\section{1 故意に大きなピッチ誤差を与えた場合}

図 3 はマーグ研削盤により故意に大きなピッチ誤差を 与えて研削した歯車を用いて式(1)の関係を検討したもの である。図において左右歯面の累積ピッチ誤差から算定 した歯みぞのふれと実測の結果がきわめてよく一致して

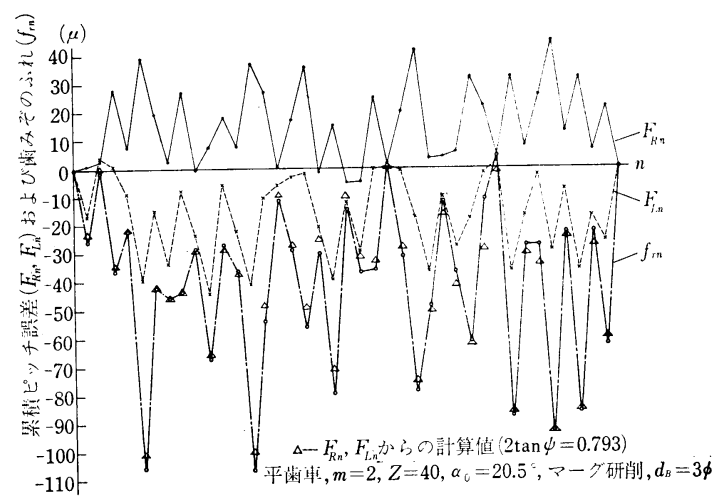

図 3 歯みぞのふれ測定例（i）

いることがわかる。

\section{2 全周を 1 周期とする累積ピッチ誤差のある場合}

歯車が工作時あるい測定時に偏心して取付けられた り，歯車加工機の親ウォームホィール京るい:割出円板 に偏心のあるときにこのような累積ピッチ誤差が生じ る。まず正しい歯車が図4 (a) に示すように $e$ だけ図示 の方向に偏心して取付けられると, 左歯面の累積ピッチ 誤差は近似的に次式で表わされる.

$$
\begin{aligned}
& F_{L n}=r\left(\beta_{2}-\beta+\xi+\eta\right), \beta_{1} \doteqdot \beta+e / r \cdot \tan \phi, \\
& \xi \fallingdotseq e / r \cdot \sin (\phi-\beta) \\
& \eta e / r \cdot \cos (\phi-\beta) \cdot \tan \alpha \\
\therefore & F_{L n}=e\{\tan \phi+\sec \alpha \cdot \sin (\phi-\psi)\}
\end{aligned}
$$

右歯面についても同様に

$$
F_{R n}=e\{-\tan \phi+\sec \alpha \cdot \sin (\phi+\phi)\}
$$

ここで $\phi=2 \pi(n-1) / Z$. 乙たがってこの場合歯みぞの ふれは式（3.1)，(3.2) を式(1) 亿代入して

$f_{r n}=e(1-\cos \phi \cdot \cos \phi / \cos \alpha) \doteqdot e(1-\cos \phi)(4)^{4)}$ 図 4 (b) 恃式 (3.1)，(3.2) と式(4)之の関係在示したもの である。つぎにマーグ研削盤に掠いて割出円板に

$$
F_{t}=e_{g} \sin \Theta_{g} \quad\left(\Theta_{g} \text { : 割出円板の回転角 }\right)
$$

で表わされる割出誤差があるものとすると $0^{\circ}$ 法により

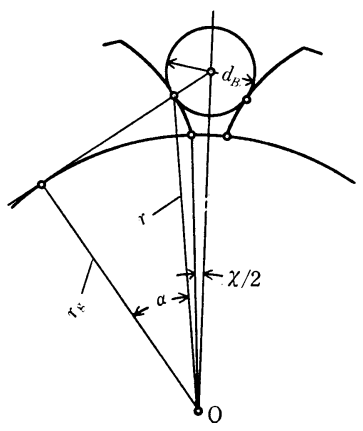

図 2 測定子と歯面の接触状態

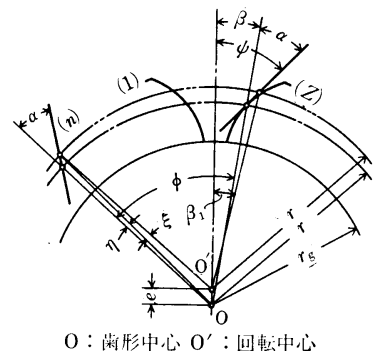

(a)

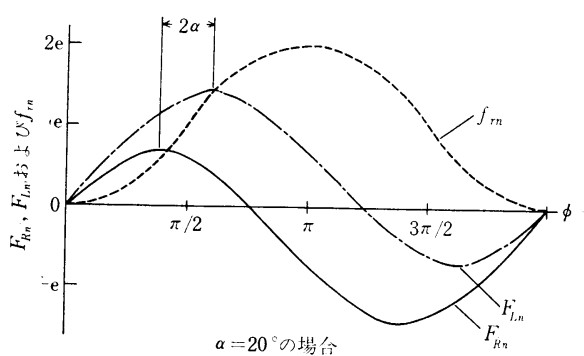

(b)

図 4 偏心した歯車の累積ピッチ誤差と歯みぞのふれ 
研削された料車には左右歯面に次式の累積ピッチ誤差が 生じる。

$$
\begin{gathered}
F_{L n}=e_{g} \cdot r / r_{0} \cdot\{\sin (\phi+\varphi)-\sin \varphi\} \\
F_{R n}=e_{g} \cdot r / r_{0} \cdot \sin \phi \\
\left(r_{0}: \text { ピッチ円半径 }\right)
\end{gathered}
$$

通常 $\varphi \fallingdotseq 2 \alpha_{0}$ にとるので，この場合の歯みぞのふれは

$$
f_{r n}=-2 e_{g} \cdot r / r_{0} \cdot \sin \alpha_{0} / \tan \psi \cdot \sin \left(\phi / 2+\alpha_{0}\right) \cdot \sin (\phi / 2)
$$

これは式(4)と同樣な曲線なので菌みぞのふれの最大值は

$f_{r n}=2 e_{g} \cdot r / r_{0} \cdot \sin \alpha_{0} / \tan \psi \fallingdotseq 2 e_{g} \cdot r / r_{0} \cdot \cos \alpha_{0}(7)$ また親ウォームホィールに偏心等により

$F_{t}=e \sin \Theta_{W} \quad\left(\Theta_{W}:\right.$ ウォームホィールの回転角 $)$ で表わされる累積ピッチ誤差があると，この歯切盤で加 エされた㐘車の左右歯面にはつぎの累積ピッチ誤差が生 じる.

$$
\left.\begin{array}{l}
F_{L n}=e \cdot r / r_{0} \cdot\{\sin (\phi+\theta+\varphi)-\sin (\theta+\varphi)\} \\
F_{R n}=e \cdot r / r_{0} \cdot\{\sin (\phi+\varphi)-\sin \varphi\}
\end{array}\right\}
$$

ここで $\theta$ は図 5 に示すように，まず初めに実線で左右歯 形を示吉状態で点 $P_{L}$ （左歯面の測定点）を切削してか ら, さらに回䎐して点線で雪形を示妇状態で点 $P_{R}$ (右歯 面の測定点 $\left.P^{\prime}{ }_{R}\right)$ を切削与るまでに歯車が回転与る看度 であり，次式で示される。

$$
\theta=2\left(\tan \alpha-\tan \alpha_{0}\right)+\pi / Z-4 x \tan \alpha_{0} / Z
$$

$\varphi$ 注正弦曲線の位相角である。そこでこの場合の歯みぞ のふ机注

$$
\begin{aligned}
f_{r n}=- & 2 e \cdot r / r_{0} \cdot \sin (\theta / 2) \cdot \sin \\
& (\phi / 2+\theta / 2+\varphi) \cdot \sin (\phi / 2) / \tan \phi
\end{aligned}
$$

こ机汸角 $\theta$ ，与なわち測定子が歯面に接する半径，いい かえれば測定子径により值が变化する。特に $\theta=0$ の点 で測定を行なえば式(10)澪になり，歯みぞのふれは現わ れない。

以上の検討から全周を 1 周期とする累積ピッチ誤差の 中で式 (3.1)，(3.2) と式(5)で示されるものは歯みぞのふ れの測定から容易に求めうることがわかる。としてその

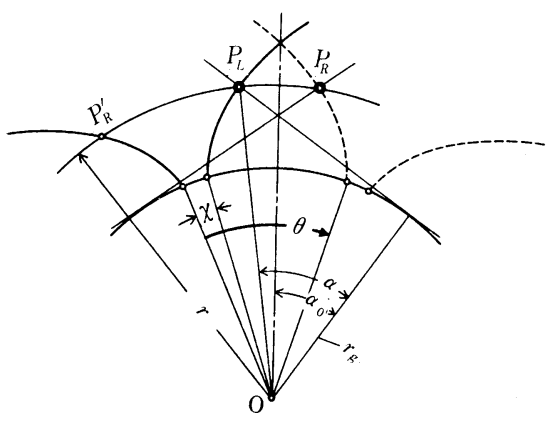

図 $5 \quad \theta$ の説明
測定結果法歯数や測定子径にはほとんど影響されない。 しかしながら式(8)で示される累積ピッチ誤差のあるとき に注測定子径により歯みぞのふれの值が種々変化して現 われるので注意を要する。

\section{3 全周に数個の周期の波を持つ累積ピッチ 誤差のある場合}

ホブ盤など一般の歯切盤の親ウォームに起因するウォ 一ム周期誤差のあるときやホブあるい:ピニオンカッタ に取付け偏心のあるときにこのような累積ピッチ誤差が 生じる。まずホブ般親ウォ一ム周期誤善について検討す る. ウォ一ム周期誤差の波の数を $J$ (ウォ一ム条数を $Z_{I}$, ウォームホィール歯数を $Z_{W}$ とすると $\left.J=Z_{W} / Z_{I}\right)$, 振幅 它 $E$ とするとウォーム周期誤差によるホブ盤ウォームホ ィールの割出誤差注近似的に

$$
F_{t}=E \sin J \Theta_{W}
$$

と表わ主ことができる。この振幅 $E$ は切削歯車上ではウ オームホィールと菌車の径の比により縮少をたは拡大さ れる他に場合によってはホブ切れ刃の干渉により縮少さ れる 振幅安 $E_{J}$ とすると左右歯面の累積ピッ千誤差汇

$$
\left.\begin{array}{l}
E_{L n}=E_{J} \cdot r / r_{0} \cdot\{\sin J(\phi+\theta+\varphi)-\sin J(\theta+\varphi)\} \\
F_{R n}=E_{J} \cdot r / r_{0} \cdot\{\sin J(\phi+\varphi)-\sin J \varphi\}
\end{array}\right\} \text { (11) }
$$

したがって歯みぞのふれは

$$
\begin{aligned}
f_{r n}= & -2 E_{J} \cdot r / r_{0} \cdot \sin (J \theta / 2) \cdot \sin J(\phi / 2 \\
& +\theta / 2+\varphi) \cdot \sin (J \phi / 2) / \tan \phi
\end{aligned}
$$

これは式(10)と同様に角 $\theta$ ， 寸なわち測定子径により值が

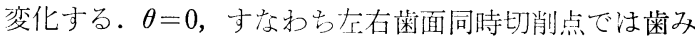
ぞのふれは現われない。したがってホブと同じ圧力角の ラック形片または円すい岁用いて歯みぞのふれを測定し たときにはこの種の誤差は検出されない， $\theta=0$ に相当 守る歯面上の圧力角は式(9)から

$$
\alpha_{z}=\tan ^{-1}\left(\tan \alpha_{0}-\pi / 2 Z+2 x \tan \alpha_{0} / Z\right)
$$

その点に接与る測定子径は式(13) 艺式(2)に代入して

$$
r_{B} / r_{g}=d_{B} / d_{g}=\pi / 2 Z-2 x \tan \alpha_{0} / Z
$$

また式(12)は $J=Z$ あるい注 $J \theta / 2=\pi, 2 \pi$ などのときにも 零になる.つぎに式(12) は $J \theta / 2=\pi / 2$ のとき最大になり， この点に相当する歯面上の圧力角法

$$
\alpha_{W}=\tan ^{-1}\left(\pi / 2 J+\tan \alpha_{0}-\pi / 2 Z+2 x \tan \alpha_{0} / Z\right) \text { (15) }
$$
その点に接する測定子径注

$$
\begin{aligned}
r_{B} / r_{g} & =d_{B} / d_{g}=\tan \left(\pi / 2 J+\alpha_{0}\right) \\
& -\left(\pi / 2 J+\tan \alpha_{0}-\pi / 2 Z+2 x \tan \alpha_{0} / Z\right)
\end{aligned}
$$

したがって式(16)から計算される径の測定子を用いて歯み ぞのふれを測定すればウォーム周期誤差を明確に求める ことができる。ただし式(16)で求められる測定子径法歯数 が多くなると歯みぞの外に出てしまい，その限界歯数は 


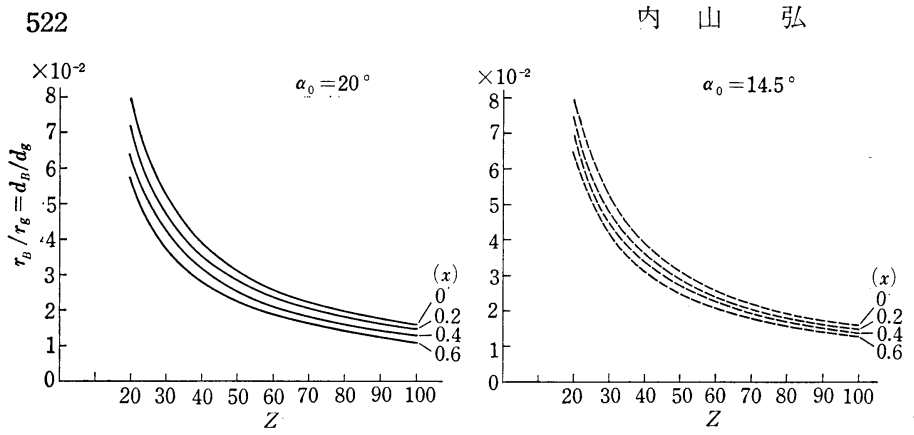

図 6 ウォーム周期誤差検出倍率零の測定子径 $(J=16$ の場合)
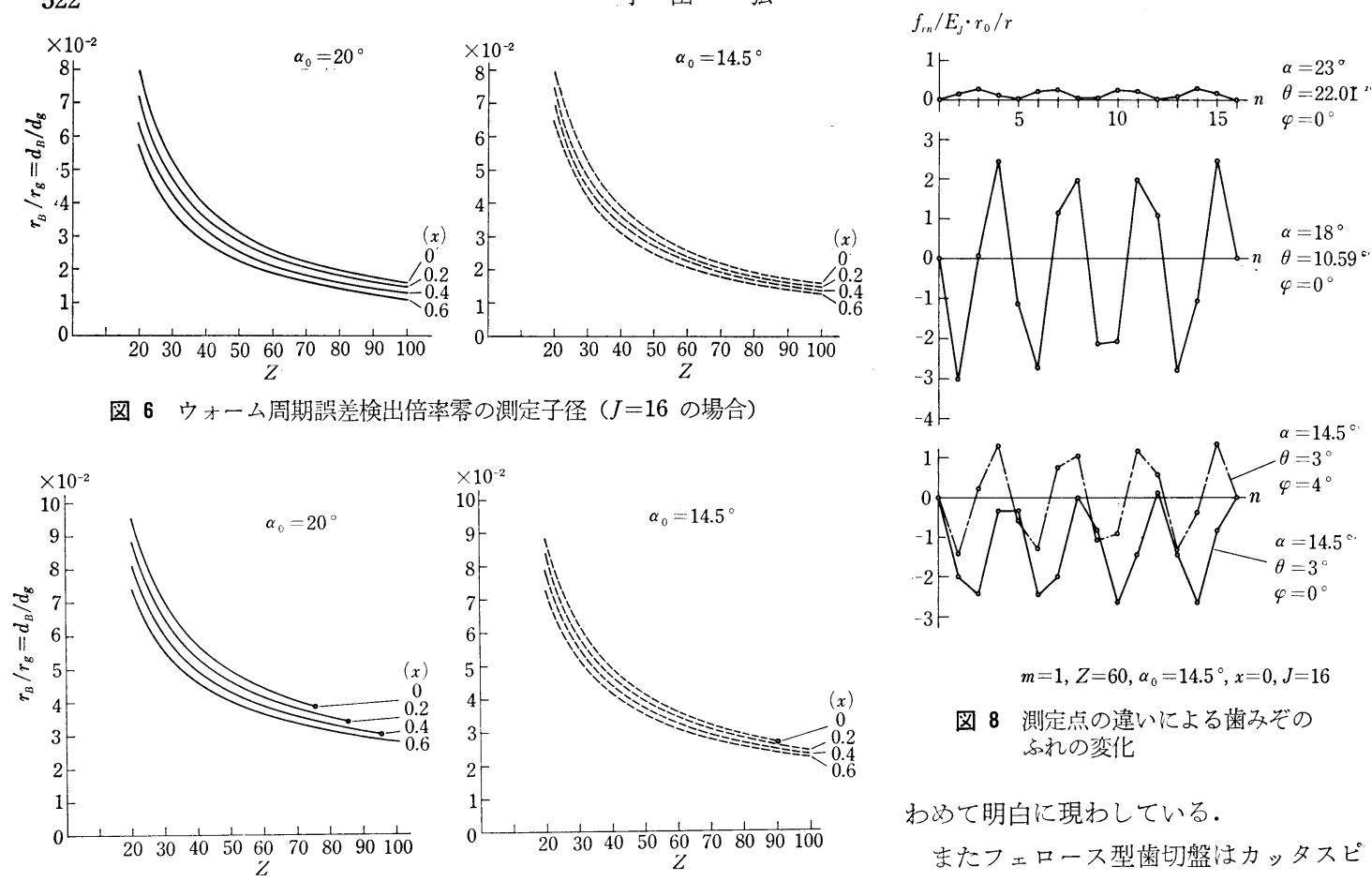

図 7 ウォーム周期誤差検出倍率最大の測定子径（ $J=16$ の場合）

$$
m=1, Z=60, \alpha_{0}=14.5^{\circ}, x=0, J=16
$$

図 8 測定点の違いによる歯みどの ふれの変化

わわて明白に現わしている。

またフェロース型歯切盤はカッタスピ ンドルにも親ウォーム歯車があるため に, この場合の歯車に移される三つのウ

測定子がちょうど歯先円に接するときであるから，歯先 円半径を $r_{K}=m(Z+2+2 x) / 2$ とするときそこの圧力角 が式(15)で示される場合に相当するので

\section{$r_{K} \cos \alpha_{W}=r_{g}$}

すなわち $\frac{m}{2}(Z+2+2 x) \cos \alpha_{W}=\frac{m}{2} \cdot Z \cos \alpha_{0}$ の関係から次式が求まる.

$$
\begin{aligned}
& \left\{\left(\pi / 2 J+\tan \alpha_{0}\right)^{2} \cos ^{2} \alpha_{0}-\sin ^{2} \alpha_{0}\right\} Z^{2} \\
& \quad-2\left\{\left(\pi / 2-2 x \tan \alpha_{0}\right)\left(\pi / 2 J+\tan \alpha_{0}\right) \cos ^{2} \alpha_{0}\right. \\
& \quad+2(1+x)\} Z+\left\{\left(\pi / 2-2 x \tan \alpha_{0}\right)^{2} \cos ^{2} \alpha_{0}\right. \\
& \left.\quad-4(1+x)^{2}\right\}=0
\end{aligned}
$$

図 6 注式(14)，図 7 注式(17)の限界条件を入れて式(16)の関係 を図示したもので $J=16$ の場合（ミクロン型ホブ盤では $\left.J=Z_{W} / Z_{I}=80 / 5=16\right)$ である. 図 8 は $\alpha$ を变えて $f_{r n}$ を 求めたもので, この例ではウォーム周期誤差の振幅と歯 みぞのふれの関係はピッチ円上（このとき測定子径は $\left.d_{B}=1.5 \phi\right)$ では $f_{r n} \fallingdotseq 2.5 E_{J}, \alpha=18^{\circ}$ の点（測定子径 $d_{B}$ $=2 \phi$ に相当する）では $f_{r n} \fallingdotseq 5 E_{J}$ である.また $\alpha=23^{\circ}$ の 点は前に述べた $J \theta / 2=\pi$ の近傍で，乙たがって歯夕ぞ のふれ注きわめて小さい。な扫では $n=16$ までを示し てあるが他は同じ值の繰返しとなる。図 9 は上で検討し た例に相当する歯車の測定例であり， $d_{B}=2 \phi$ の測 定子 による歯みぞのふれの測定結果はウォーム周期誤差をき
ォーム周期誤差による左右歯面の累積ピッチ誤差は二つ のウォーム周期誤差の差となる少ら

$$
\begin{aligned}
F_{L n} & =E_{W} \cdot r / r_{0}\left\{\sin Z_{W}\left(\xi / Z+\theta+\varphi_{1}\right)-\sin Z_{W}\left(\theta+\varphi_{1}\right)\right\} \\
& -E_{s} \cdot r / r_{0}\left\{\sin Z_{s}\left(\xi / Z_{c}+Z \theta / Z_{c}+\varphi_{2}\right)\right. \\
& \left.-\sin Z_{s}\left(Z \theta / Z_{c}+\varphi_{2}\right)\right\} \\
F_{R n} & =E_{W} \cdot r / r_{0}\left\{\sin Z_{w}\left(\xi / Z+\varphi_{1}\right)-\sin Z_{W} \varphi_{1}\right\} \\
& -E_{s} \cdot r / r_{0}\left\{\sin Z_{s}\left(\xi / Z_{c}+\varphi_{2}\right)-\sin Z_{s} \varphi_{2}\right\}
\end{aligned}
$$

(18)

ここで

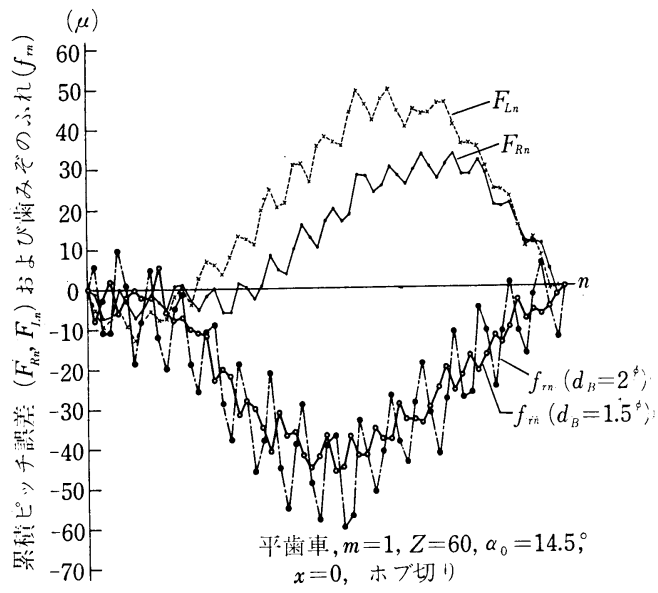

图 9 歯みぞのふれ測定例 (ii) 


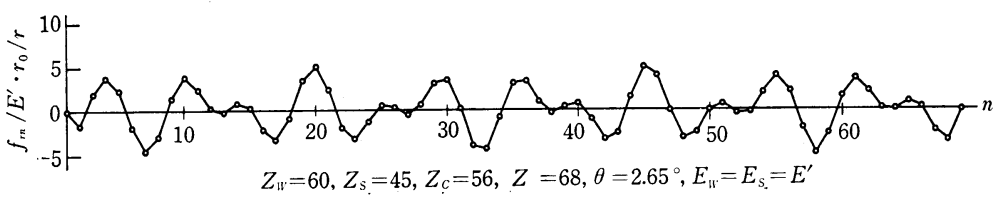

図 10 フェロース型歯切盤で歯切りされた歯車に現われる歯みぞのふれの計算例

$E_{W}$ ：ワークテーブルウォーム周期誤差の歯車ピッ チ円上に移された振幅

$E_{s} \quad$ ：カッタスピンドルウォーム周期誤差の歯車 ピッチ円上に移された振幅

$Z_{W}:$ ワークテーブルウォームホィール歯数

$Z_{s}$ : カッタスピソドルウォームホィール歯数

$Z_{c}:$ ピニオンカッタ歯数

$\varphi_{1}, \varphi_{2}$ : 位相角, $\xi=2 \pi(n-1)$

そこで蒾みぞのふれは

$f_{r n}=-2 \cdot r / r_{0} \cdot\left\{E_{W} \sin \left(Z_{W} \theta / 2\right) \cdot \sin \left(\xi Z_{W} / 2 Z\right)\right.$

$\cdot \sin Z_{W}\left(\xi / 2 Z+\theta / 2+\varphi_{1}\right)-E_{s} \sin \left(Z_{s} Z \theta / 2 Z_{c}\right)$

$\cdot \sin \left(\xi Z_{s} / 2 Z_{c}\right) \cdot \sin \left(\xi / 2 Z_{c}+Z \theta / 2 Z_{c}\right.$

$\left.\left.+\varphi_{2}\right)\right\} \cdot / \tan \psi$

この場合も $\theta=0$ のときには歯みぞのふれは現われない. 他の点で演車の歯数とカッタの歯数の関係, あるいは 位相角の関係で種々変化した蒾叒ぞのふれが現われる。 式(19)において $E_{W}=E_{s}=E^{\prime}, \varphi_{1}=\varphi_{2}=0$ としたときの計 算の一例を図 10 に示す。 $E^{\prime}$ がわずか $1 \mu$ でおおよそ 10 片菌みぞのふれが現われることがわかる。

つぎにホブに偏心 $e_{h}$ がある場合には図 11 からら，ホブ の回転角を $\omega$ とすると

$F_{t}=e^{\prime}{ }_{h} \tan \alpha_{0}, \quad e^{\prime}{ }_{h} \fallingdotseq e_{h} \sin \omega$

また $Z_{h}$ をホブの条数と与るとホブの回転角と歯車の回 転角之の間には $\omega=Z / Z_{h} \cdot \phi$ の関係があるので, これを

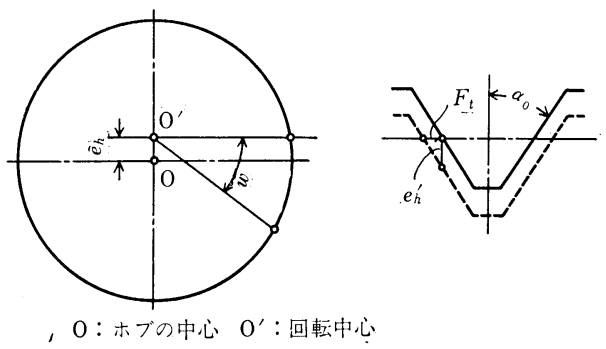

図 11 ホブの偏心と累積ピッチ誤差

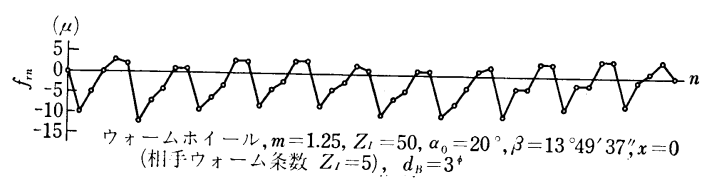

図 12 歯みぞのふれ測定例（iii）
上式に代入して

$$
F_{t}=e_{h} \tan \alpha_{0} \cdot \sin \left\{2 \pi(n-1) / Z_{h}\right\}
$$

したがって歯車にはつぎの累積ピッチ誤差が生じる.

$$
F_{t n}=e_{h} \cdot r / r_{0} \cdot \tan \alpha_{0} \cdot\left[\sin \left\{2 \pi(n-1) / Z_{h}+\varphi_{h}\right\}\right.
$$

$\left.-\sin \varphi_{h}\right]$

(20)

ここで $\varphi_{h}$ は位相角である。この場合には左右歯面の累 積ピッチ誤差は絶対值が等しく符号法反対になるので, 歯みぞのふれは

$$
\begin{aligned}
f_{r n}= & -2 e_{h} \cdot r / r_{0} \cdot \tan \alpha_{0} \cdot \sin \left\{\pi(n-1) / Z_{h}\right\} \\
& \cdot \cos \left\{\pi(n-1) / Z_{h}+\varphi_{h}\right\} / \tan \phi
\end{aligned}
$$

$Z_{h}=1$ のときには歯みぞのられは現われない. $Z_{h}=2$ の ときには $\varphi_{h}$ により菊みどのふれが現われないときと $e_{h}$ の $4 r / r_{0} \tan \phi$ 倍に現わ机るときがある. 図 12 汇 $Z_{h}=$ 5 の例であり，ホブ 1 回転ごとにきわめて明りょうに歯 みぞのふれが現われている。ピニオンカッタに偏心のあ る場合も同様にカッタ 1 回転を 1 周期とする歯みぞのふ れが現われる。

\section{4 左右歯面に同じ累積ピッチ誤差のある場合}

成形歯切りあるい成形研削法により加工された歯車 またはマーグ $15^{\circ}$ 法により研削された歯車は, その加工 法上各歯の割出しが不連続のため, 值は小さいけれども 多数の不規則な波からなる累積ピッチ誤差を有してい る。しかしながら，この場合常に歯みぞの幅法一定とい う特徵があるために，いいかえれば $F_{L n}=F_{R n}$ であるた めに歯文でのふれは現われない。

以上各種累積ピッチ䛊差と歯みぞのふれとの関係につ いて検討したものをまとめると，

(1)3.2で検討したように偏心量を適確に求めることが できる。そしてその值は測定子径には影響されない。

(2)ウォーム周期誤差は測定子径により検出倍率が変 わる。ウォーム周期誤差の有無を知りたいときには式(16) による径の測定子を用いて測定を行なえばよい，

(3)多条ホブあるい注ピニオンカッタの取付け偏心も, タい出すことができる。

\section{4. オーバピン法と歯みぞのふれ}

ピンまたは玉を歯みぞに入れて測定を行なう点では， オーバピン（玉）法と歯みぞのふれはまったく同じであ る・したがって歯みぞのふれを有する歯車をオーバピン 


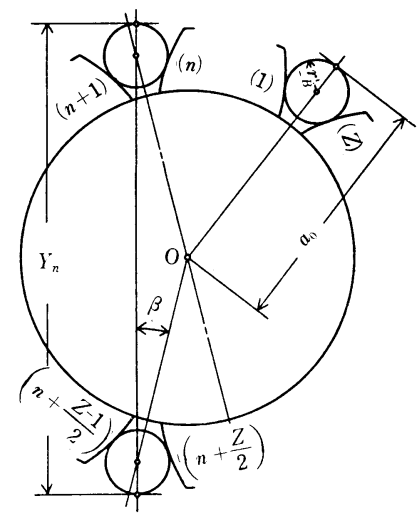

図 13 オーバピン(玉)法の説明

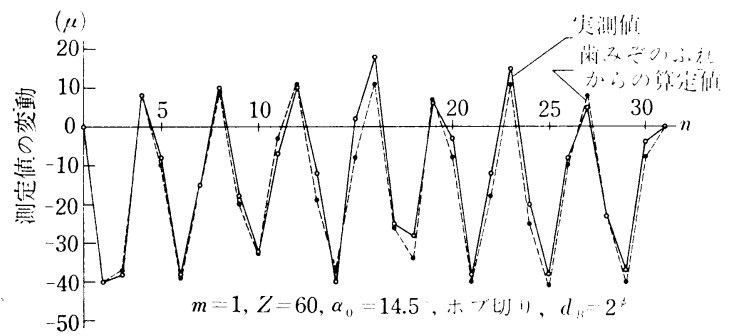

図 14 オーバピン法による測定例

法で測定すれば，測定する歯みどにより測定值に湋いが でることは当然予想さ机る。ここでは，このオーバピン

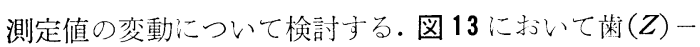
(1) 間に入れた玉の歯車の中心からの距離を $a_{0}$ とおくと, このときのオーバピン測定值は

$$
\begin{aligned}
Y_{1} & =\left\{a_{0}+r_{B}(1 / \cos \beta-1)\right\} \cos \beta \\
& +\left\{a_{0}+f_{r(Z-1 / 2)}+r_{B}(1 / \cos \beta-1)\right\} \cos \beta \\
& =\left\{2 a_{0}+2 r_{B}(1 / \cos \beta-1)+f_{r(Z-1 / 2)}\right\} \cos \beta
\end{aligned}
$$

ここで $\beta=\pi / 2 Z$. したがって菊 $(n)-(n+1)$ とに相当 するオーバンピン測定值は

$$
Y_{n}=\left\{2 \alpha_{0}+2 r_{B}(1 / \cos \beta-1)+f_{r n}+f_{r(n+Z+1 / 2)}\right\} \cos \beta
$$

それ故 $Y_{1}$ を基準にしたときの測定值の変動法

$$
\Delta Y_{n}=\left\{f_{r n}+f_{r(n+Z-1 / 2)}-f_{r(Z-1 / 2)}\right\} \cos \beta
$$

歯数が偶数の場合には $\beta=0$ とおいて

$$
\Delta Y_{n}=\left\{f_{r n}+f_{r(n+Z / 2)}-f_{r(Z / 2)}\right\}
$$

測定值に法本来偏心の影響は入らないので, 各測定值に 変動があれば，主な原因としてウォ一ム周期誤差が考元 られる。この測定には, ウォーム周期誤差の影響しない

\begin{tabular}{|c|c|c|}
\hline $\begin{array}{l}\text { 測定方法 } \\
\text { 誤差項目 }\end{array}$ & 歯みぞのふれ測定 & 両歯面かみあい試験 \\
\hline 検出できる誤差 & $\begin{array}{l}\text { 歯車の偏心 } \\
\text { 工具の取付偏心 } \\
\quad(1 \text { 条ホブは除く) } \\
\text { マーグ研削盤の割出 } \\
\text { 誤差 } \\
\quad \text { (0 法の場合) } \\
\text { ウォーム周期誤差 }\end{array}$ & $\begin{array}{l}\text { 歯車の偏心 } \\
\text { 工具の取付偏心 } \\
\text { マーグ研削盤の割出 } \\
\text { 誤差: } \\
\quad \text { (0法の場合) } \\
\text { 压力角誤差 }\end{array}$ \\
\hline $\begin{array}{l}\text { 検出できない詥 } \\
\text { 差 }\end{array}$ & $\begin{array}{l}\text { 压力角誤差 } \\
\text { 左甭面まったく同 } \\
\text { じ累積ピッチ誤差 }\end{array}$ & $\begin{array}{l}\text { ウォーム周期䛊差 } \\
\text { 左右歯面まったく同 } \\
\text { じ累積ピッ誤差 }\end{array}$ \\
\hline $\begin{array}{l}\text { 検出できるが量 } \\
\text { 的関倸莣決めら } \\
\text { 机ない䛊差 }\end{array}$ & $\begin{array}{l}\text { 左右歯面まったく不 } \\
\text { 則樏な積ピッチ誤 } \\
\text { 疘 }\end{array}$ & 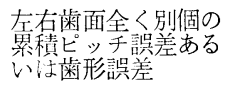 \\
\hline
\end{tabular}
式(14)で求まるような小さい径の玉法使用できない場合が 多いので, 測定結果にはウォ一ム周期誤差の影響が入り やすく，その上場合によってはウォーム周期誤差が蒌み ぞのふれのときの 2 倍に現わ机ることがある. 図 14 は
表 1 歯みぞのふれ測定と両苗面かみあい試験との比較

測定の一例であり，歯車は図 9 に菊久ぞのふれを示した ものと同じである。式(23)よる㐘みぞのふ机からの計算 值と実測值と泳かりよく一致している。この例からも 明らかのようにオーバピン測定值はウォーム周期誤差あ るいは多条ホブまたはピニオンカッタなど工具偏心の影 響を受けや导いので, 数力所で测走を行ない, それら誤 差の影響を考慮する必要がある。

\section{5. 両歯面かみあい試験との比較}

歯多ぞに基準片を入れて菌車半径方向に対与る変位を

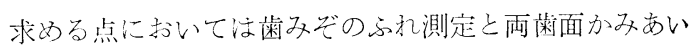
試験は類似であるけれぞも，歯みぞのふれが各歯みぞか ら一つの情報しか得られないのに対して両蒾面かみあい 試験の場合に㳉菌面全体に接寸るために, きわめて多数 の情報が得られるという違いがある。最近両菌面かみあ い試験で検出しうる誤差が明らかにされた6) ので，それ とこ机をで検討した菌みだのふ机とを比較対照したのが 表1である。歯車の偏心流いずれの測定でも検出しうる が，目立った相違点としては両歯面か力亦い試験注，1 歯面にかかわる誤差, 寸なわら压力角誤差や一条木ブの 偏心による菊形誤差を検出しうるのに対し，歯みぞのふ れは数㐘にまたがる誤差，すなわらウォーム周期誤差を 検出しうることがあげられる。

\section{6. むすび}

以上歯みぞのふれ測定ととれに関連することがらにつ いて検討した結果をまとめるとつぎのようになる。

(1)歯反ぞのふ机注左右菊面の累積ピッチ誤差から合成 して求めることができる。したがって萪みぞのふ机注，

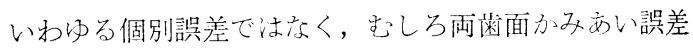
の特殊な場合に相当する。 
(2)蒾車の编心量劣よびウォーム周期誤差の測定には有 効である. 特に编心のみが問題となるような高精度歯車 に洼適している。

(3) JIS $\left.{ }^{7}\right)$ で活測定子はピッチ円上に接するものを使用 するように規定しているけれども，ウォーム周期誤差の ある歯車では歯数へより測定值が大きく変わるので, JIS の規定法不適当で市る。偏心量のみを求めたい場合に は，式(14)こよる測定子径を用いるのが望ましい。

(4)ウォー二周期誤差を検出したい場合には式(16)による 測定子径を用いるのぶ望ましい。

(5)オーパピン測定值もウォーム周期誤差等の影響を受 ける。

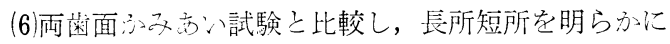
した.

終りにご指導いだ゙てている東工大精密工学研究所石
川二郎教授，富井正男博士に感謝申上げる．また面倒な 数値計算を打願いした長田秀治氏にお礼申上げる.

\section{文献}

1) $\left(\pi / 2 Z-\operatorname{inv} \alpha_{0}\right)$ は数表が作製されているJ. Peters: Kreis-und Evolventen-Funktionen, Fred. Dümmlers Verlag, Berlin und Bonn (1937) 199.

2) 仙波正荘：歯車， 2 日刊工業新聞社，(1966) 391 .

3）新荘謹一：歯ミゾに入れた玉の出入り，歯車工業32(1957) 28.

4) 次の交献に同様の結果が示されている. 和栗 明, 他 5 名: 歯車の設計と製作，日本機械学会（1956） 189.

5）石橋 彰：循環䛊差の歯形精度におよぼす影響，日本機械 学会論交集 $28,187(1962-3) 350$.

6）富井正男：歯車の 2 歯面かみあい試験について，日本機械 学会論交集 35，272（1969-4）890.

7) JIS B 1702 (1960) 平歯車およびハスバ歯車の精度および B 1752 (1962) 平歯車およびハスバ歯車の測定方法. 